\title{
Pengembangan Sistem Pemetaan Lokasi Tempat Wisata Taman Mini Indonesia Indah Berbasis Mobile
}

\author{
Septian Eka Nurhuda' ${ }^{1)}$, Nuraini Purwandari' ${ }^{2)}$ \\ Sistem Informasi, Fakultas Industri Kreatif Institut Teknologi dan Bisnis Kalbis \\ Jalan Pulomas Selatan Kav. 22, Jakarta 13210 \\ ${ }^{1)}$ septian.en12@gmail.com \\ ${ }^{2)}$ nuraini.purwandari@kalbis.ac.id
}

\begin{abstract}
Taman Mini Indonesia Indah is one of the tourist attraction in DKI Jakarta.There was a problems caused by the wide area of TMII. It's confusing the visitors to know the route to the facility which addressed. At each intersection around the TMII area there is a road sign, but the information displayed is not concise and overlapping. The purpose of this research is to develop TMII location mapping system. The development method used is Rapid Application Development (RAD). The results of this study in the form of android applications that can help TMII visitors in knowing the direction to go to the location of TMII.
\end{abstract}

Keywords: android, application, mapping, RAD, TMII.

\begin{abstract}
Abstrak: Taman Mini Indonesia Indah adalah salah satu objek wisata yang terdapat di DKI Jakarta. Terdapat permasalahan yang diakibatkan oleh luasnya area TMII, sehingga sering membuat bingung para pengunjung untuk mengetahui rute menuju lokasi fasilitas yang dituju. Pada setiap persimpangan jalan, di sekitar area TMII telah tersedia papan petunjuk jalan, namun informasi yang ditampilkan tidak ringkas dan saling bertumpuk. Tujuan dari penelitian ini adalah untuk mengembangkan sistem pemetaan lokasi TMII. Metode pengembangan yang digunakan adalah Rapid Application Development (RAD). Hasil dari penelitian ini berupa aplikasi android yang dapat membantu pengunjung TMII dalam mengetahui arah untuk menuju lokasi fasilitas di TMII.
\end{abstract}

Kata kunci: android, aplikasi, pemetaan, RAD, TMII

\section{PENDAHULUAN}

DKI Jakarta memiliki banyak tempat wisata yang bervariasi, seperti kebun binatang, pantai, taman bermain, sampai tempat yang dianggap sebagai versi kecil dari Indonesia, yaitu Taman Mini Indonesia Indah (TMII). Tempat - tempat wisata yang ada di Jakarta masih sangat diminati oleh pengunjung, terutama saat hari libur. Namun dengan banyaknya jumlah pengunjung yang datang, bukan berarti tidak terdapat kekurangan pada tempat wisata tersebut. Seperti misalnya pada Taman Mini Indonesia Indah yang memiliki luas area hingga sekitar 150 hektar.

Berdasarkan data yang peneliti dapatkan dari hasil kuesioner yang diikuti oleh 55 orang pengunjung TMII, lebih dari $90 \%$ responden berpendapat bahwa peta yang disediakan dapat menampilkan seluruh

lokasi fasilitas TMII. Namun $60 \%$ diantaranya berpendapat bahwa peta sulit dipahami. Begitu juga dengan papan petunjuk arah yang disediakan, lebih dari $70 \%$ pengunjung setuju bahwa papan petunjuk arah menampilkan informasi yang bertumpuk.
Kelemahan peta dan papan petunjuk arah yang disediakan TMII seringkali membingungkan pengunjung. Seperti yang terlihat pada Gambar, di mana terdapat pengunjung yang mengendarai sepeda motor menanyakan arah kepada petugas yang berjaga. Padahal tepat di depannya terdapat sebuah papan petunjuk arah, Gambarl.

Sangat disayangkan di era kemajuan teknologi seperti saat ini, tempat wisata sebesar TMII tidak dapat memanfaatkan teknologi untuk menyediakan peta atau papan petunjuk arah yang lebih baik. Padahal saat ini DKI Jakarta sedang berkembang untuk menjadi kota pintar (smart city). Di mana DKI

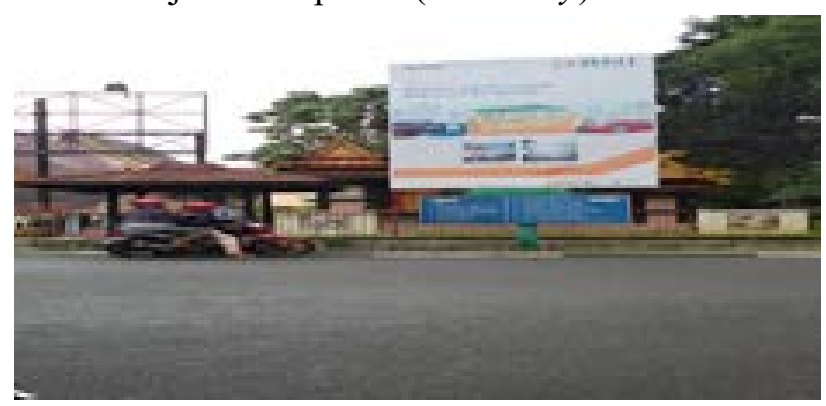

Gambar 1 Pengunjung Bertanya Arah 
Jakarta ingin menerapkan teknologi pada setiap sektor publik, dan TMII sebagai tempat wisata merupakan salah satu sektor publik yang dimiliki Jakarta.

Dengan ini, permasalahan yang akan dipecahkan dalam penelitian ini adalah sistem informasi seperti apa yang dapat memberikan informasi petunjuk arah dan informasi budaya di area TMII secara cepat dan jelas. Sehingga tujuan dari penelitian ini adalah untuk mengembangkan sistem pemetaan lokasi di objek wisata Taman Mini Indonesia Indah, dan menyediakan informasi budaya dari masing - masing anjungan daerah di Taman Mini Indonesia Indah.

\section{METODE PENELITIAN}

Metode penelitian adalah sekumpulan langkah teratur yang dilaksanakan untuk mendapatkan hasil dari sebuah penelitian.

\section{A. Kerangka Berpikir}

Kerangka berpikir merupakan cara berpikir peneliti dalam menghadirkan solusi dari penelitian ini. Adapun kerangka berpikir peneliti dapat dilihat pada Gambar 2. Kerangka berpikir dimulai dari perumusan masalah, kemudian pengumpulan data melalui kuesioner, wawancara, observasi, dan studi literatur. Lalu dilanjutkan dengan analisis sistem berjalan, identifikasi masalah dan analisis solusi. Kemudian tahap terakhir adalah melakukan pengembangan sistem dengan metode RAD.

\section{Perumusan Masalah}

Pada tahap ini peneliti berfokus untuk mencari permasalahan yang sedang terjadi, khususnya yang terjadi di sekitar tempat tinggal peneliti yaitu Provinsi DKI Jakarta. Perumusan masalah berawal dari pengalaman pribadi peneliti, sampai dengan pendapat masyarakat. Perumusan masalah berguna untuk menjadi acuan dalam mengidentifikasi masalah berdasarkan fakta-fakta yang ditemukan di lapangan Permasalahan yang sering dialami oleh pengunjung tempat wisata terdiri dari: (1) Area tempat wisata sangat luas, namun papan petunjuk arah yang disediakan tidak lengkap dan tidak jelas; dan (2) Nilai edukasi yang seharusnya diterima oleh pengunjung, tidak dapat tersampaikan dengan baik.

\section{Pengumpulan Data}

Peneliti menggunakan 4 metode dalam pengumpulan data, yaitu observasi lapangan, penyebaran kuesioner, wawancara dan studi literatur.

- Observasi Lapangan

Berdasarkan data hasil observasi lapangan, peneliti menemukan fakta bahwa terdapat banyak

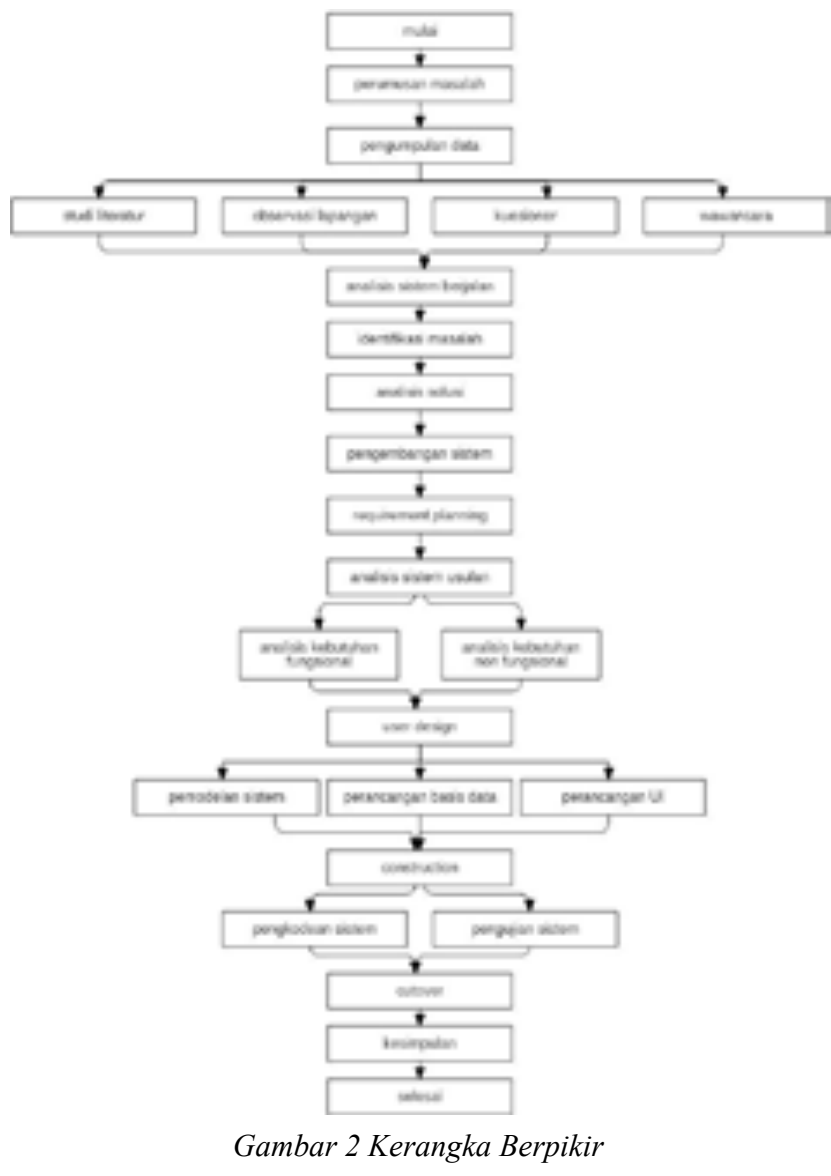

pengunjung yang masih memilih untuk bertanya arah kepada petugas yang berjaga, dibandingkan melihat papan petunjuk arah yang berada di depannya.

\section{- Kuesioner}

Penyebaran kuesioner dilakukan untuk mengetahui pendapat pengunjung mengenai peta dan papan petunjuk arah yang disediakan oleh pihak pengelola TMII. Terdapat 55 pengunjung yang menjadi responden. Hasil dari kuesioner tersebut dapat dilihat pada Tabel 1.

Lebih dari $90 \%$ pengunjung menyetujui bahwa peta yang disediakan TMII dapat menampilkan seluruh lokasi fasilitas yang ada. Namun tidak sedikit pula yang menganggap peta sulit untuk dipahami, dan berpendapat bahwa sebaiknya jumlah peta ditambah dan ukurannya diperbesar. Begitu juga dengan papan petunjuk arah yang dinilai harus dibuat menjadi lebih ringkas, karena informasi yang ditampilkan terlalu bertumpuk.

\section{- Wawancara}

Peneliti turut melakukan wawancara dengan pihak pengelola TMII yaitu dengan Ibu Fitriana selaku Kepala Bagian SIM dan LITBANG, Taman Mini Indonesia Indah. Hasil wawancara tersebut menghasilkan kesimpulan bahwa TMII memerlukan sistem pemetaan yang lebih baik. Apabila memungkinkan dengan menggunakan smartphone 
milik pengunjung, maka solusi tersebut akan menjadi solusi yang sangat baik, karena lebih mudah dijangkau oleh pengunjung serta menghemat biaya jika dibandingkan dengan pembuatan papan petunjuk arah.

\section{- Studi Literatur}

Data terakhir yang peneliti kumpulkan berasal dari studi literatur. Dengan membaca penelitianpenelitian terdahulu dengan topik sejenis, peneliti dapat mengetahui apa kekurangan dari penelitian yang telah dilakukan sebelumnya, sehingga penelitian ini dapat menghasilkan solusi yang lebih baik.

Penelitian terdahulu yang peneliti gunakan untuk menjadi perbandingan adalah penelitian yang dilakukan oleh Ghilman Hasbi Basith dengan judul Perancangan Sistem Informasi Pemetaan Pariwisata Garut Berbasis Geografic Information System dan Android. Penelitian kedua dilakukan oleh He Gang dengan judul Applied research on mobile tourism scenic spots integrated system based on Android.

\section{Analisis Sistem Berjalan}

Pada tahap ini peneliti akan melakukan analisis terhadap proses yang dilakukan oleh pengunjung TMII, terutama saat mencari rute menuju lokasi tujuan dan mencari informasi budaya Indonesia. Analisis ini bertujuan untuk menemukan kelemahan dari sistem yang berjalan saat ini.

Tabel 1 Hasil Kuesioner Peta TMII

\begin{tabular}{llllll}
\hline \hline No & Pernyataan & STS & TS & S & SS \\
\hline 1 & $\begin{array}{l}\text { Peta dapat } \\
\text { menampilkan } \\
\text { seluruh lokasi } \\
\text { fasilitas di } \\
\text { TMII }\end{array}$ & $0 \%$ & $7,3 \%$ & $69,1 \%$ & $23,6 \%$ \\
\hline 2 & $\begin{array}{l}\text { Peta sulit untuk } \\
\text { dipahami }\end{array}$ & $0 \%$ & $40 \%$ & $43,6 \%$ & $16,4 \%$ \\
\hline 3 & $\begin{array}{l}\text { Peta harus } \\
\text { diperbanyak }\end{array}$ & $0 \%$ & $5,5 \%$ & $56,4 \%$ & $38,2 \%$ \\
\hline 4 & $\begin{array}{l}\text { Peta harus } \\
\text { diperbesar }\end{array}$ & $0 \%$ & $5,5 \%$ & $41,8 \%$ & $52,7 \%$ \\
\hline & $\begin{array}{l}\text { Papan petunjuk } \\
\text { arah } \\
\text { menampilkan } \\
\text { informasi yang } \\
\text { bertumpuk }\end{array}$ & $0 \%$ & $27,3 \%$ & $45,5 \%$ & $27,3 \%$ \\
\hline 6 & $\begin{array}{l}\text { Papan petunjuk } \\
\text { arah harus } \\
\text { dibuat menjadi } \\
\text { lebih ringkas }\end{array}$ & $0 \%$ & $14,5 \%$ & $58,2 \%$ & $27,3 \%$ \\
\hline 7 & $\begin{array}{l}\text { Peta dan } \\
\text { petunjuk arah } \\
\text { lebih baik jika } \\
\text { dijadikan } \\
\text { aplikasi } \\
\text { berbasis mobile } \\
\text { android) }\end{array}$ & $0 \%$ & $3,6 \%$ & $47,3 \%$ & $49,1 \%$ \\
\hline & & & & \\
\hline
\end{tabular}

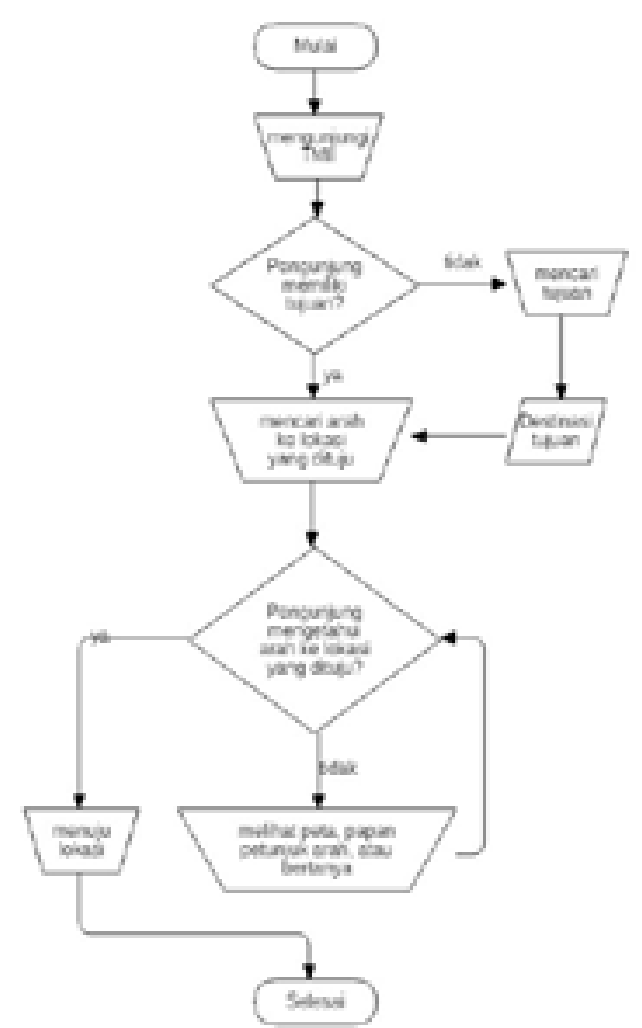

Gambar 3 Sistem berjalan Pencarian Lokasi

Sampai saat ini, untuk mengetahui arah menuju lokasi tujuannya, pengunjung masih mengandalkan peta dan papan petunjuk arah yang tersedia di TMII. Langkah-langkah yang sering dilakukan oleh pengunjung untuk menuju lokasi tujuannya dapat dilihat pada Gambar 3.

Pada Gambar 3 dapat dilihat bahwa pengunjung membutuhkan tujuan dalam kunjungannya ke TMII. Namun tidak semua pengunjung memiliki tujuan spesifik saat mengunjungi TMII. Dengan tidak adanya tujuan spesifik untuk mengunjungi salah satu fasilitas di TMII, bukan berarti pengunjung-pengunjung tersebut hanya akan berputar-putar mengelilingi area TMII. Biasanya pengunjung akan menemukan lokasi tujuannya setelah mengelilingi area TMII.

Setelah memiliki tujuan, pengunjung akan berusaha untuk menuju lokasi dari fasilitas atau wahana tujuannya. Pengunjung bisa langsung menuju lokasi tujuannya jika sudah mengetahui rute yang harus ditempuh. Namun yang menjadi kendala adalah tidak semua pengunjung mengetahui rute untuk menunju lokasi tujuannya. Oleh sebab itu, pihak pengelola TMII menyediakan peta di beberapa sudut area TMII, serta papan petunjuk arah di setiap persimpangan jalan TMII yang dapat dimanfaatkan oleh pengunjung.

Setelah pengunjung dapat menuju lokasi tujuannya, tidak ada jaminan bahwa pengunjung akan langsung mendapatkan informasi mengenai 
budaya Indonesia. Langkah-langkah yang biasanya dilakukan oleh pengunjung dalam mencari informasi budaya Indonesia dapat dilihat pada Gambar 4.

Pengunjung yang ingin mencari informasi budaya Indonesia dapat menuju ke anjungan daerah yang mewakili provinsi-provinsi di Indonesia. Mengunjungi masing-masing anjungan daerah untuk mencari informasi budaya Indonesia masih bisa dilakukan jika pengunjung datang ke TMII bukan pada musim liburan. Namun akan menjadi sangat tidak efisien, jika pengunjung harus mengunjungi seluruh anjungan daerah di TMII, untuk mengetahui budaya dari seluruh provinsi di Indonesia. Ditambah lagi pada hari libur jumlah pengunjung TMII semakin meningkat, sehingga sering mengakibatkan arus lalu lintas di area TMII menjadi terhambat, dan lahan parkir di setiap anjungan daerah tidak dapat menampung seluruh kendaraan milik pengunjung. Kendala ini juga yang menjadi alasan bagi banyak pengunjung untuk tidak menjadikan pencarian informasi budaya Indonesia sebagai tujuan utamanya dalam mengunjungi TMII. Hal ini sangat disayangkan karena visi utama dari dibangunnya TMII adalah untuk mengenalkan bahwa budaya Indonesia kepada seluruh pengunjung.

Berdasarkan analisis sistem berjalan tersebut dapat disimpulkan bahwa proses yang dilakukan oleh

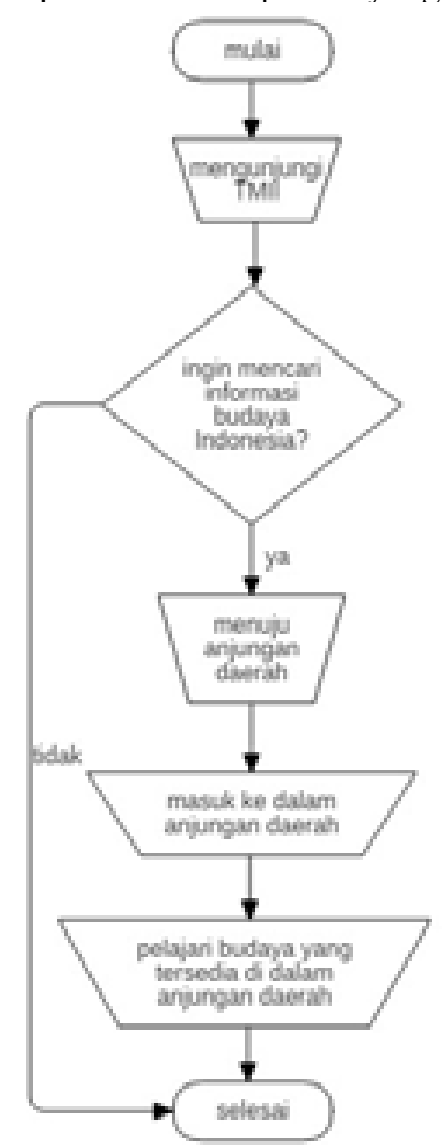

Gambar 4 Sistem Berjalan Pencarian Info Budaya pengunjung dalam mengetahui arah untuk menuju lokasi tujuannya terlalu rumit. Selain itu proses yang perlu dilakukan oleh pengunjung untuk mengetahui informasi budaya sangat tidak efektif dan efisien, karena mengharuskan pengunjung untuk mendatangi setiap anjungan daerah jika ingin mengetahui informasi budaya dari setiap daerah.

\section{Identifikasi Masalah}

Setelah seluruh data terkumpul dan sistem yang berjalan telah dianalisis, maka dapat diidentifikasi fakta yang tidak sesuai dengan harapan, atau bisa juga disebut sebagai masalah.

Dengan mempertimbangkan hasil dari analisis sistem berjalan dan data yang telah dikumpulkan, baik melalui observasi maupun kuesioner yang diisi oleh pengunjung TMII, permasalahan yang dihadapi oleh pengunjung TMII adalah sebagai berikut: Jumlah peta TMII masih terlalu sedikit, sehingga sulit untuk dijumpai; Ukuran peta masih terlalu kecil untuk mencakup seluruh area TMII, sehingga harus dilihat dari jarak dekat; Papan petunjuk arah yang tersedia cukup banyak, namun informasi yang ditampilkan terlalu bertumpuk dan sulit untuk dipahami; dan Proses pencarian rute menuju lokasi yang dituju dan pencarian informasi budaya tidak efisien.

\section{Analisis Solusi}

Setelah masalah teridentifikasi dan data pendukung telah berhasil terkumpul, maka tahap selanjutnya adalah menganalisis solusi dari permasalahan yang sedang dihadapi.

Berdasarkan data mengenai jumlah pengguna internet di dunia, Indonesia menempati peringkat kelima sebagai negara dengan jumlah pengguna internet terbanyak. Lebih dari 100 juta warga Indonesia sudah terbiasa menggunakan internet dalam kegiatan sehari-hari [1]. Dengan adanya data ini, maka internet dapat digunakan untuk menyampaikan informasi mengenai arah menuju lokasi yang dituju oleh pengunjung.

Menurut situs statista.com, $62 \%$ dari total seluruh pengguna internet di Indonesia mengakses internet melalui perangkat mobile [2]. Sistem operasi untuk mobile phone yang paling banyak digunakan di Indonesia adalah Android. Sampai dengan bulan Oktober 2017, jumlah pengguna sistem operasi Android telah mencapai angka 85,46\% dari seluruh mobile phone di Indonesia [3].

Selain memiliki jumlah pengguna yang banyak, dan telah menjadi sistem operasi mayoritas perangkat mobile di Indonesia, Android juga memiliki fitur yang lengkap. Salah satunya adalah memiliki GPS dan dapat diintegrasikan dengan Google Maps. 
Dari pembahasan di atas dapat disimpulkan bahwa solusi dari permasalahan yang dihadapi oleh pengunjung TMII adalah sistem yang dapat menunjukan arah sekaligus dapat memberikan informasi budaya Indonesia, dengan memanfaatkan internet, dan dapat diterima melalui smart phone atau tablet android milik pengunjung. Solusi ini diperkuat oleh $96 \%$ pengunjung yang mengisi kuesioner, dengan menyepakati pemanfaatan smart phone atau tablet Android untuk menjadi peta pribadi pengunjung.

\section{Pengembangan Sistem}

Metode pengembangan sistem yang digunakan adalah Rapid Application Development (RAD). Langkah-langkah yang dilakukan dalam pengembangan sistem adalah sebagai berikut:

\section{a. Requirement Planning}

Pada tahap ini akan dibahas mengenai hasil dari analisis sistem usulan, yang terdiri dari analisis kebutuhan fungsional dan non fungsional. Berdasarkan hasil dari analisis solusi yang sudah dilakukan, dapat disimpulkan bahwa kebutuhan utama dari sistem adalah pemetaan lokasi dan penyediaan informasi budaya. Sistem yang diusulkan dibuat seringkas mungkin untuk memangkas proses panjang yang dilakukan oleh pengunjung TMII, pada saat mencari arah maupun mencari informasi budaya saat ini.

Berdasarkan hasil analisis sistem usulan dan hasil wawancara dengan pengelola TMII maka didapatlah daftar kebutuhan fungsional seperti yang terlihat pada tabel 2 .

\section{b. User Design}

Pada tahap ini peneliti akan membuat pemodelan sistem, rancangan basis data, dan rancangan tampilan antarmuka atau user interface (UI). Perancangan sistem ini terdiri dari tiga tahap, yaitu pemodelan

\section{Tabel 2 Kebutuhan Fungsional}

\begin{tabular}{|c|c|}
\hline Aktor & Deskripsi \\
\hline $\begin{array}{l}\text { Pengunjung } \\
\text { TMII }\end{array}$ & $\begin{array}{ll}\text { a. } & \text { Sistem dapat menampilkan daftar } \\
\text { fasilitas yang dimiliki TMII } \\
\text { b. Sistem dapat menampilkan daftar acara } \\
\text { yang diselenggarakan oleh TMII } \\
\text { c. Sistem dapat menampilkan daftar } \\
\text { provinsi di Indonesia } \\
\text { d. Sistem dapat menampilkan informasi } \\
\text { budaya dari masing-masing provinsi di } \\
\text { Indonesia } \\
\text { e. Sistem dapat menunjukan rute untuk } \\
\text { menuju lokasi fasilitas TMII } \\
\text { f. Sistem dapat menunjukan rute untuk } \\
\text { menuju lokasi acara yang } \\
\text { diselenggarakan TMII } \\
\text { g. Sistem dapat menunjukan rute untuk } \\
\text { menuju lokasi anjungan daerah sesuai } \\
\text { dengan provinsi Indonesia } \\
\text { h. Sistem dapat menampilkan peta TMII }\end{array}$ \\
\hline
\end{tabular}

sistem, perancangan basis data, dan perancangan tampilan antar muka.

Model sistem dibuat dengan menggunakan software starUML, dengan versi UML 2.0. Terdapat tiga buah model sistem yang dibuat pada penelitian ini, yaitu use case diagram, activity diagram, dan class diagram.

\section{HASIL DAN PEMBAHASAN}

\section{A. Referensi}

Demi tersedianya penjelasan yang valid serta dapat dipertanggungjawabkan, peneliti turut mengutip penjelasan dari para ahli mengenai teoriteori serta penelitian terdahulu yang sesuai dengan topik penelitian ini.

\section{Penelitian Terdahulu}

Penelitian dengan topik sistem pemetaan lokasi tempat wisata telah dilakukan oleh beberapa peneliti lain. Dua penelitian yang menjadi pembanding dari penelitian ini dibuat oleh Ghilman Hasbi Basith dari Indonesia dan $\mathrm{He}$ Gang dari Cina.

Kedua penelitian tersebut sama-sama membuat sistem pemetaan lokasi untuk tempat wisata. Sistem pemetaan lokasi tersebut dikembangkan pada perangkat mobile dengan sistem operasi android. Kedua penelitian tersebut sama-sama menggunakan google Maps. Kesamaan tersebut menjadi dasar bagi peneliti dalam menentukan solusi dari permasalahan yang dihadapi oleh pengunjung TMII.

Namun yang membedakan penelitian ini dengan kedua penelitian terdahulu adalah penggunaan method Ground Overlay untuk mengetahui batas area TMII dengan area di luarnya. Selain itu, informasi mengenai budaya Indonesia turut menjadi pembeda antara penelitian ini dengan penelitian terdahulu. Penelitian yang dilakukan oleh Ghilman tidak turut menyertakan informasi mengenai budaya Garut, begitu juga dengan penelitian He Gang yang tidak menyertakan informasi mengenai budaya Cina yang ada di dalamnya.

\section{Konsep Dasar Sistem Informasi}

Sistem informasi secara sederhana dapat diartikan sebagai sistem yang menghasilkan informasi. Sistem sendiri adalah sekumpulan objek, ide, berikut keterkaitannya di dalam mencapai tujuan [4]. Sedangkan informasi berarti data yang telah ditempatkan pada konteks yang penuh arti oleh penerimanya [4]. Data adalah bentuk awal dari informasi yang belum diolah. Data dapat diartikan 
sebagai bahasa, mathematical, dan atau simbol pengganti lain yang disepakati secara umum dalam mengGambarkan suatu objek, manusia, peristiwa, aktivitas, konsep, atau objek penting lainnya [4].

\section{Konsep Dasar Pemetaan}

Peta dapat diartikan sebagai Gambar atau lukisan pada kertas dan sebagainya yang menunjukkan letak tanah, laut, sungai, gunung dari suatu daerah yang menyatakan sifat, seperti batas daerah, sifat permukaan, dan lain sebagainya [5]. Sifat-sifat dari permukaan bumi tersebut dikumpulkan dan dijadikan aktivitas dari sebuah aplikasi, inilah yang disebut sebagai sistem pemetaan [6]. Sistem pemetaan akan selalu berkaitan dengan data dari permukaan bumi. Selain itu, pemetaan juga selalu berhubungan dengan koordinat dari suatu lokasi di bumi.

\section{Mobile Device}

Mobile device berkaitan dengan mobilitas, berukuran kecil, yang berfungsi sebagai media komunikasi dan informasi, seperti smart phone atau PDA [6]. Perangkat mobile memerlukan sebuah sistem operasi atau perangkat lunak yang mengatur sumber daya dan aplikasi komputer agar dapat digunakan oleh pengguna [6]. Salah satu contoh sistem operasi untuk perangkat mobile adalah Android.

\section{Android}

Setiap perangkat komputer pada zaman ini memiliki sistem operasi untuk membantu pengguna dalam mengoperasikannya. Tidak terkecuali untuk perangkat mobile. Definisi sistem operasi ialah perangkat lunak yang mengatur sumber daya dan aplikasi komputer agar dapat digunakan oleh pengguna [6]. Terdapat berbagai jenis sistem operasi untuk perangkat mobile seperti misalnya iOS, android, windows, blackberry, dan lain sebagainya.

Android adalah tumpukan perangkat lunak berbasis Linux yang dibuat untuk berbagai perangkat. [7] Android merupakan sistem operasi untuk perangkat mobile yang paling banyang digunakan di dunia. Tidak terkecuali di Indonesia, Android menjadi sistem operasi yang paling banyak digunakan oleh masyarakat Indonesia. Data pada tahun 2017 menunjukan bahwa pada tahun 2017 jumlah pengguna android di Indonesia mencapai $85 \%$ dari seluruh sistem operasi mobile yang digunakan di Indonesia [3].

Telah terdapat berbagai versi android yang telah dikembangkan sejak tahun 2014. Setiap versi diberi kode yang diambil dari nama makanan-makanan manis di dunia. Versi android yang telah beredar adalah cupcake, donut, éclair, frozen yogurt, ginger bread, honey comb, ice cream sandwich, jelly bean, kitkat, lollipop, marshmallow, nougat, serta yang terbaru yaitu oreo.

\section{Pemodelan Sistem}

Pemodelan sistem diperlukan untuk mempermudah proses komunikasi antara pengguna (user) dengan pengembang (developer) sistem.

Salah satu cara memodelkan sistem adalah dengan menggunakan Unified Modelling Language (UML). UML adalah bahasa pemodelan yang berbentuk diagram atau notasi yang digunakan untuk menentukan, memvisualisasikan, membangun dan mendokumentasikan komponen pemodelan bisnis, perangkat lunak dan bahkan sistem non perangkat lunak [8].

UML terdiri dari 13 tipe diagram yang diantaranya adalah class diagram, object diagram, package diagram, component diagram, composite structure diagram, deployment diagram, use case diagram, activity diagram, state machine diagram, sequence diagram, communication diagram, interaction overview diagram, dan timing diagram [8]. Namun yang akan digunakan pada penelitian ini terbatas hanya pada use case diagram, activity diagram, serta class diagram.

\section{Basis Data}

Basis data adalah himpunan kelompok data yang saling berhubungan, yang diorganisasi sedemikian rupa agar dapat dimanfaatkan kembali dengan cepat dan mudah [9]. Pengelolaan basis data dari penelitian ini menggunakan layanan Firebase Cloud Firestore yang disediakan oleh Google. Firebase Cloud Firestore menggunakan model basis data non relasional yang dapat diartikan sebagai basis data yang tidak menggunakan model tabel seperti yang digunakan pada basis data model relasional (relational database), melainkan menggunakan model key-value [10].

\section{Metode Pengembangan Sistem}

Metode pengembangan sistem yang digunakan dalam penelitian ini adalah Rapid Application Development (RAD). RAD digunakan untuk menghadirkan sistem secara lebih cepat. Dalam proses pengembangannya, RAD memiliki tiga komponen utama yaitu prototyping, iterative, dan time box [11].

Prototyping adalah solusi untuk menghadirkan sistem secara cepat. Pengguna dapat mencoba sistem 
secara bertahap selama proses pengembangan. Setiap terjadi penambahan fitur disebut dengan iterative. Sedangkan time box digunakan untuk membagi waktu kerja berdasarkan fitur yang akan diimplementasikan ke dalam sistem. Setiap time box akan terdiri dari 4 langkah, yaitu requirements planning, user design, construction, dan cutover [12], dapat dilihat pada Gambar 5.

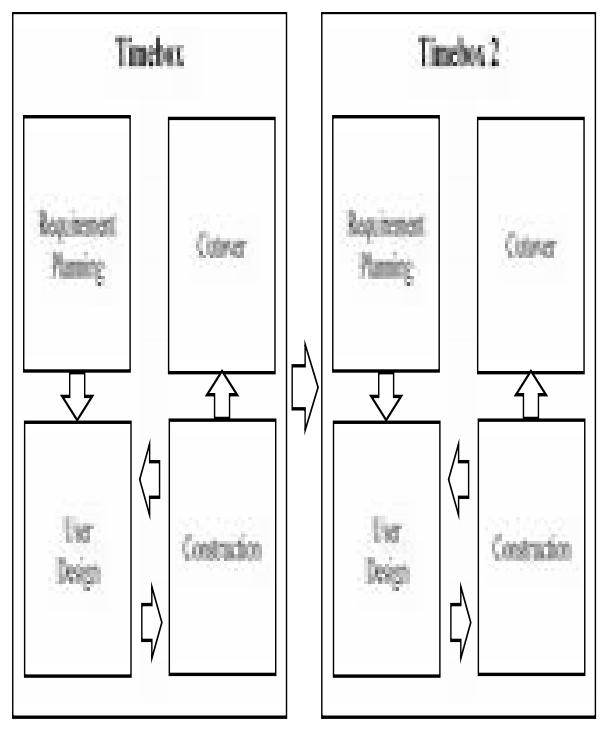

Gambar 5 Langkah RAD

\section{B. Hasil Pengembangan Sistem}

Hasil pengembangan sistem akan dibedakan menjadi dua bagian yaitu hasil pengkodean sistem dan hasil pengujian sistem

\section{- Pengkodean Sistem}

Pengkodean sistem diperlukan untuk membuat aplikasi sesuai dengan rancangan yang telah dibuat sebelumnya. Proses pengkodean sistem dilakukan oleh peneliti sendiri tanpa melibatkan pengunjung maupun pengelola TMII. Aplikasi PETA TMII dibuat dengan menggunakan Integrated Development Environment (IDE) yang bernama Android Studio. Pengkodean

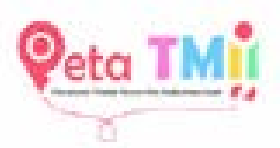

Gambar 6 Hasil Splash Screen

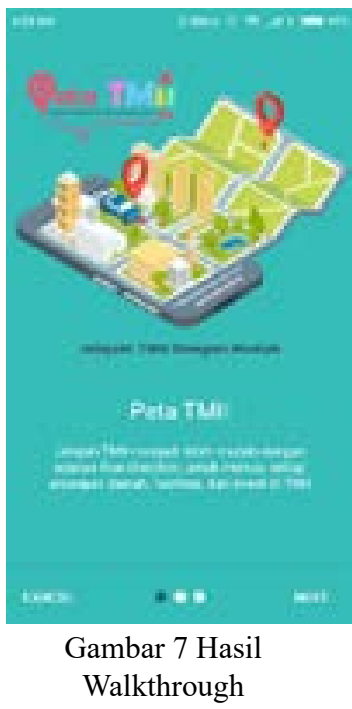

aplikasi pada Android Studio menggunakan bahasa Java. Setelah proses pengkodean sistem selesai dilakukan, maka tampilan aplikasi PETA TMII akan menjadi seperti Gambar 6 dan 7.

Hasil dari tampilan splash screen seperti yang terlihat pada Gambar 6, sesuai dengan rancangan tampilan yang telah dibuat pada tahap perancangan UI. Logo PETA TMII yang ditampilkan, peneliti buat dengan menggunakan Adobe Illustrator CS6.

Setelah menampilkan splash screen, selanjutnya peta TMII menampilkan halaman pengenalan aplikasi (walkthrough). Halaman walkthrough hanya akan muncul satu kali, pada saat pengguna pertama kali membuka aplikasi PETA TMII. Hasil tampilan 7 walkthrough dapat dilihat pada Gambar 8.

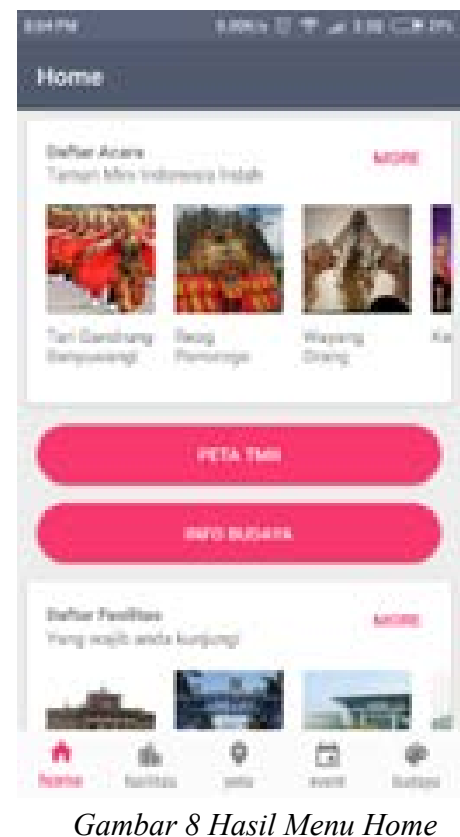

Setelah melewati tampilan splash screen dan walkthrough aplikasi PETA TMII langsung menampilkan menu home, yang menjadi menu awal. Hasil dari tampilan menu home dapat dilihat pada Gambar 8.

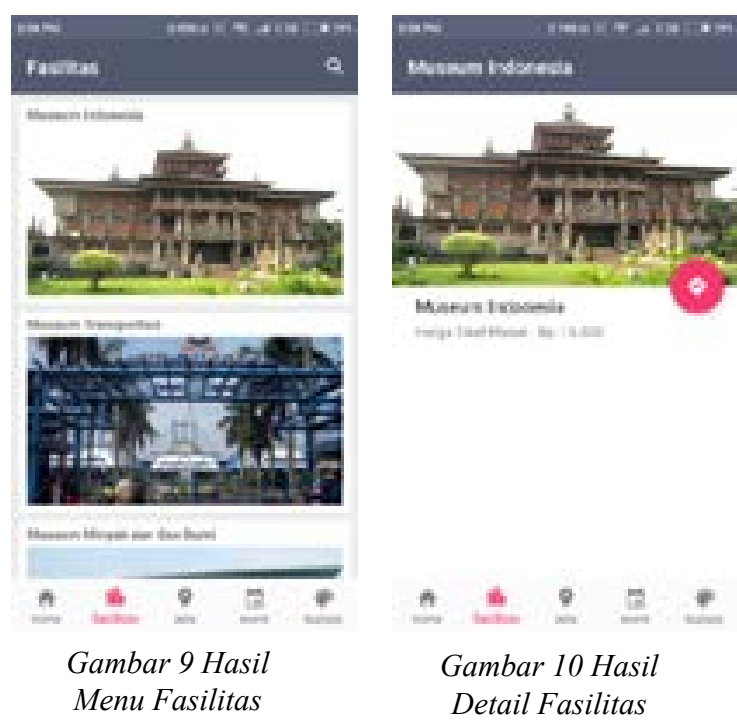




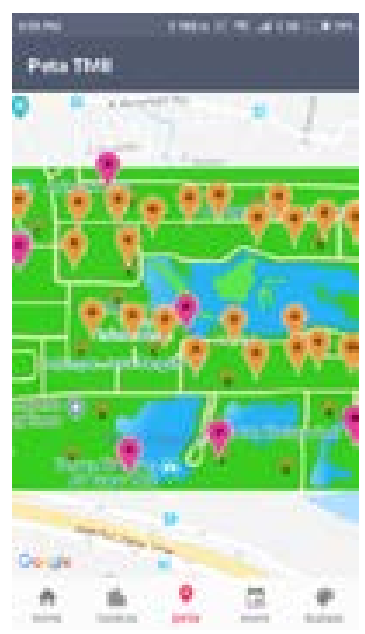

Gambar 11

Hasil Menu Peta

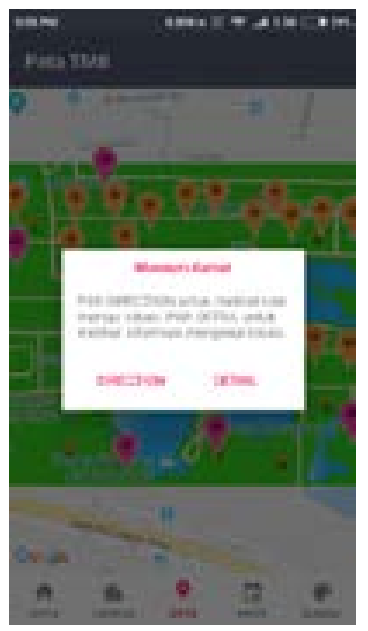

Gambar 12

Hasil Dialog
Menu fasilitas dapat dibuka jika pengguna memilih menu fasilitas, atau menekan tombol "more" yang terdapat pada daftar aplikasi di menu home. Hasil tampilan menu fasilitas dapat dilihat pada Gambar 9 dan 10.

Hasil tampilan menu peta dapat dilihat pada Gambar 11. Untuk mempermudah pengguna dalam mengetahui perbedaan marker lokasi fasilitas dan lokasi anjungan, peneliti menggunakan dua warna yang berbeda, yaitu oranye dan merah muda.

Gambar 12 merupakan contoh dialog yang akan muncul jika salah satu marker ditekan. kotak dialog akan menawarkan dua pilihan bagi pengguna. Pilihan yang ditawarkan diGambarkan dengan dua buah tombol, yang diberi nama "direction" dan "detail."

Hasil dari tampilan menu acara sesuai dengan rancangan yang dibuat. Aplikasi menampilkan daftar acara, beserta tanggal diselenggarakannya acara tersebut. Hasil tampilan menu acara dapat dilihat pada Gambar 13. Jika pengunjung memilih salah satu dari daftar acara yang tersedia, maka tampilan akan berubah seperti yang terlihat pada Gambar 14 .
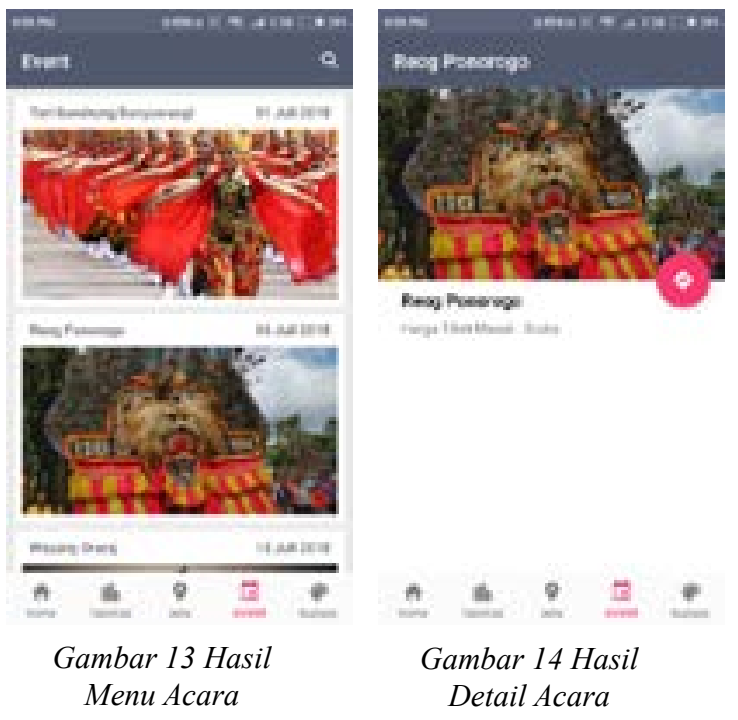

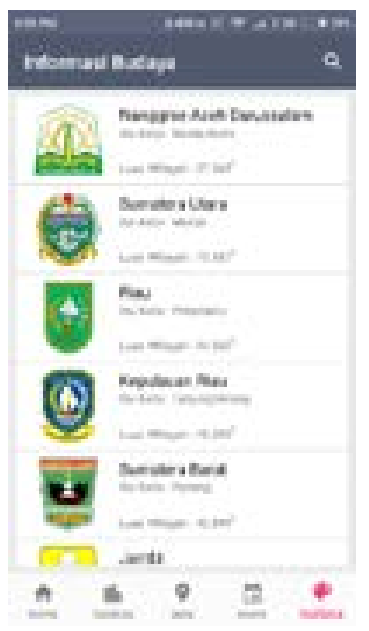

Gambar 15 Hasil Menu Info Budaya

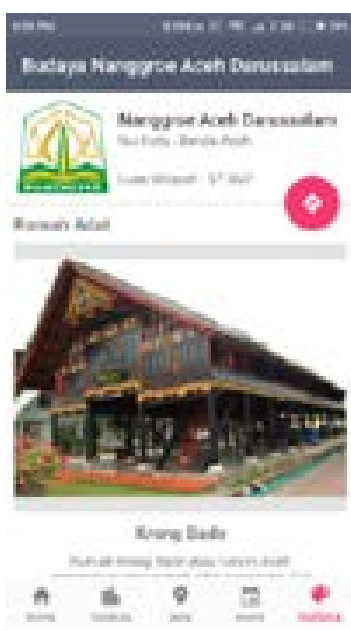

Gambar 16 Hasil Detail Info Budaya
Pada Gambar 15 dapat dilihat bahwa peneliti meletakan tombol "direction" berwarna merah di sisi kanan layar, dengan tujuan agar dapat lebih mudah dijangkau oleh pengguna. Hal ini dikarenakan mayoritas masyarakat Indonesia lebih dominan menggunakan tangan kanan saat mengoperasikan smart phone.

Tampilan menu info budaya dibuat sesuai dengan hasil rancangan UI yang telah dibuat. Menu info budaya dapat menampilkan daftar daerah seperti yang terlihat pada Gambar 15.

Apabila pengguna memilih salah satu daerah, maka tampilan akan berubah menjadi seperti pada Gambar 16. Dapat dilihat bahwa aplikasi PETA TMII dapat menampilkan rumah adat dari provinsi Nanggroe Aceh Darussalam.

\section{- Pengujian Sistem}

Setelah sistem berhasil dibuat, maka tahap selanjutnya adalah melakukan pengujian sistem. Pengujian sistem dilakukan dengan metode Black Box Testing. Sehingga pengujian sistem akan bedakan menjadi dua jenis pengujian, yang pertama adalah alpha testing dan yang kedua adalah beta testing [13].

- Pengujian alpha

Dilakukan untuk menguji coba seluruh fitur dari aplikasi PETA TMII. Pengujian ini dilakukan oleh Ibu Fitriana selaku Kepala Bagian SIM dan LITBANG, Taman Mini Indonesia Indah. Skenario pengujian dibuat untuk mengetahui keberhasilan setiap fitur dan menu yang dimiliki oleh PETA TMII. Berdasarkan hasil pengujian alpha yang telah dilakukan oleh penguji, dapat disimpulkan bahwa aplikasi PETA TMII tidak mengalami kegagalan fungsionalitas. Semua fitur berjalan sesuai dengan apa yang diharapkan. Dapat disimpulkan juga bahwa aplikasi PETA TMII dapat diterima dengan baik oleh pihak TMII. 
- Pengujian beta

Dilakukan oleh masyarakat umum yang pernah mengunjungi Taman Mini Indonesia Indah. Pengujian ini dilakukan dengan cara mengisi kuesioner yang terdiri dari 10 butir pernyataan, dan diikuti oleh 15 orang responden dengan 15 tipe smartphone yang berbeda. Hasil pengujian beta menunjukan bahwa lebih dari 14 dari dari 15 responden tidak mengalami kendala saat menggunakan aplikasi PETA TMII. Hanya terdapat 1 responden yang mengalami masalah, yaitu pada saat mencoba untuk melihat rute untuk menuju lokasi diselenggarakannya acara TMII. Namun di luar 1 masalah tersebut, penilaian akan aplikasi PETA TMII sudah cukup baik.

\section{SIMPULAN}

Berdasarkan hasil penelitian mengenai Pengembangan Sistem Pemetaan Lokasi tempat Wisata Taman Mini Indonesia Indah Berbasis Mobile, yang telah dilakukan dan telah dilakukan pengujian, maka dapat ditarik kesimpulan bahwa sistem pemetaan berbasis mobile dapat membantu pengunjung TMII dalam mengetahui arah untuk menuju lokasi fasilitas yang ingin dituju. Sehingga dengan adanya aplikasi PETA TMII dapat membantu mereduksi kebingungan pengunjung terhadap informasi yang disediakan melalui peta maupun papan petunjuk.

Selain itu aplikasi PETA TMII juga dapat membantu dalam menyampaikan informasi budaya Indonesia, sebagaimana visi dari TMII yang ingin mengenalkan budaya Indonesia kepada seluruh pengunjung baik dari dalam negeri maupun luar negeri. Dengan adanya aplikasi yang dapat menjadi petunjuk arah sekaligus memberikan informasi budaya kepada pengunjung melalui layar smart phone masing-masing, tentu hal ini dapat meningkatkan kualitas kegiatan berwisata pengunjung, yang semula hanya untuk mengisi waktu luang, menjadi kegiatan wisata yang turut membawa nilai edukasi.

\section{DAFTAR RUJUKAN}

[1] Statista, "Statistics : Statista," Maret 2017. [Online]. Available: https://www.statista.com/statistics/262966/ number-of-internet-users-in-selected-countries/. [Accessed 20 Oktober 2017].
[2] Statista, "Study : Statista," 2012. [Online]. Available: https://www.statista.com/study/22622/internet-usagein-indonesia-statista-dossier/. [Accessed 20 Oktober 2017].

[3] Statista, "statistics : statista.com," Statista, 2018. [Online]. Available: https://www.statista.com/ statistics/262205/market-share-held-by-mobileoperating-systems-in-indonesia/. [Accessed 25 Juli 2018].

[4] E. Prahasta, Sistem Informasi Geografis : KonsepKonsep Dasar (Perspektif Geodesi dan Geomatika), Bandung: Informatika, 2014.

[5] Kementerian Pendidikan dan Kebudayaan, "KBBI entri : Kemdikbud," [Online]. Available: https://kbbi. kemdikbud.go.id/entri/peta. [Accessed 9 April 2018].

[6] M. Khosrow-Pour, Dictionary of Information Science and Technology (2nd-Edition), United States of America: IGI Global, 2013.

[7] Android, "Guide : Developer Android," Google, [Online]. Available: https://developer.android.com/ guide/platform/?hl=id. [Accessed 2 May 2018].

[8] S. G. D Jeya Mala, Object Oriented Analysis and Design Using UML, New Delhi: McGraw Hill Education, 2013.

[9] R. Yanto, Manajemen Basis Data Menggunakan MySQL, Yogyakarta: Deepublish, 2016.

[10] G. C. Deka, NoSQL: Database for Storage and Retrieval of Data in Cloud, London: Chapman and Hall/CRC, 2017.

[11] W. K. Safrian Aswati, "Rancang Bangun Sistem Informasi Data Karyawan Kantor Notaris/PPAT Mulia Ginting Suka,” Jurnal Teknologi dan Sistem Informasi, vol. 1, pp. 1-7, 2014.

[12] M. N. A. K. Riffat Naz, "Rapid Applications Development Techniques: A Critical Review," International Journal of Software Engineering and Its Applications, vol. 9, pp. 163-176, 2015.

[13] M. Kumar and S. K. Singh, "A Comparative Study of Black Box Testing and White Box Testing Techniques," International Journal of Advance Research in Computer Science and Management Studies, vol. 3, no. 10, pp. 32-44, 2015. 